3 Consensus for Maternal, Newborn and Child Health. http://www.who. int/pmnch/events/2009/20090922_consensus.pdf (accessed May 10, 2010).

4 G8 Leaders Declaration. Responsible leadership for a sustainable future. Para 122. http://www.g8italia2009.it/static/G8_Allegato/G8 Declaration_08_07_09_final,0.pdf (accessed May 10, 2010).

5 Commission on Macroeconomics and Health. Macroeconomics and health: investing in health for economic development. Report of the Commission on Macroeconomics and Health; Dec 20, 2001. http:// www.emro.who.int/cbi/pdf/CMHReportHQ.pdf (accessed May 26, 2010).

6 Cometto G, Ooms G, Starrs A, Zeitz P. A global fund for the health MDGs? Lancet 2009; 373: 1500-02.

7 High Level Taskforce on Innovative International Financing for Health Systems. More money for health, and more health for the money. http:// www.internationalhealthpartnership.net//CMS_files/documents/ taskforce_report_EN.pdf (accessed May 10, 2010).
8 Exploring options for optimizing synergies with maternal and child health: decision point GF/B21/DP20. April 30, 2010. http://www.theglobalfund. org/documents/board/21/GF-BM21-DecisionPoints_en.pdf (accessed May 10, 2010).

9 WHO. Maximising positive synergies between health systems and global health initiatives. 2008. http://www.who.int/healthsystems/ MaximizingPositiveSynergies.pdf (accessed May 10, 2010).

10 Sankore R. A call for a massive paradigm shift from just health financing to integrated health, population and social development investment in Africa: the case for progressing from only $15 \%$ to $15 \%$ plus. Health Financing Paper for AU July 2010 Summit preparatory meeting, Addis Ababa; April 21, 2010. http://www.equinetafrica.org/bibl/docs/ SANFIn23052010.pdf (accessed May 26, 2010).

11 ASADI. Science in action: saving the lives of Africa's mothers, newborns and children. 2009. http://www.who.int/pmnch/topics/continuum/2009_ scienceinaction/en/index.html (accessed May 10, 2010).

\title{
HIV and maternal mortality: turning the tide
}

The two top causes of death in women of reproductive age globally are HIV/AIDS and complications related to pregnancy and childbearing, which account for $19 \%$ and $15 \%$ of all deaths in women aged 15-44 years, respectively. ${ }^{1}$ The growing burden of HIV infection in young sexually active women and the maternal health problems that they face have been described as two intersecting epidemics. ${ }^{2}$ In settings with a high HIV burden and high maternal mortality ratios, especially in sub-Saharan Africa, many HIV-infected

\section{The printed journal includes an image merely for illustration}

pregnant women are confronted not only with the risk of death associated with advancing HIV disease, but also with an increased risk of pregnancy-related death.

The relative risk of pregnancy-related death in women infected with HIV compared with that in non-infected women ranges from just over double in one hospital-based study in South Africa to about 13 in a study of women having caesarean deliveries in the USA..$^{3-11}$ Although these studies varied in size and quality, usually including 100 or fewer maternal deaths, there is compelling evidence of increased risk of maternal death in women infected with HIV from nationwide confidential inquiries into facility-based deaths in pregnant women in South Africa. ${ }^{11}$ These inquiries, which have been done since 1997, have shown a steady increase in the number of maternal deaths over time. Although part of the increase is attributable to improved reporting, there are also real increases in deaths associated with rising rates of HIV infection in pregnant women. Between 2005 and 2007, the facility-based maternal mortality ratio in South Africa was nearly ten times higher in women known to be HIV-positive than in women known to be HIV-negative (328/100 000 livebirths compared with 34/100 000 livebirths). ${ }^{11}$

Understanding the dimensions and pathways of the increased risk of death in pregnant women with HIV infection is constrained by incomplete and inaccurate data on numbers and causes of maternal deaths. Moreover, unanswered questions about the biological interactions between HIV infection and pregnancy 
remain. Although it is generally assumed that deaths in HIV-infected pregnant women are largely due to advancing HIV disease and related comorbidities, such as tuberculosis and malaria, evidence from South Africa suggests that HIV infection might also increase the risk of maternal death by increasing the risk of dying from direct obstetric complications (associated with abortion, haemorrhage, and sepsis). ${ }^{11}$ Compromised immune status and disease interactions provide an immediate biological explanation for the increased risk of maternal death in HIV-infected pregnant women.

Additionally, the risk might be increased due to contextual factors such as poor access to or inadequate quality of health care provided to women infected with HIV, who often face substantial stigma and discrimination from health-care workers and community members. These are particular concerns for adolescents with HIV. In South Africa, the confidential inquiries have identified failures of the health-care system, including substandard care, as main contributors to avoidable maternal deaths, and these problems seem to be exacerbated when the mother is infected with HIV. There are reports of substandard care leading to failures to provide appropriate treatment for those in need, and inadequate management of obstetric emergencies in HIV-infected pregnant women. ${ }^{11}$ On the other hand, the recent scaleup of HIV services has, in some settings, resulted in wideranging improvements in health systems that might have contributed to improving maternal health in both HIV-infected and uninfected women. . $^{12,13}$

The realisation that HIV is holding back progress in reaching Millennium Development Goal 5 on maternal health, at least in sub-Saharan Africa, ${ }^{14}$ has spurred welcome discussions about mechanisms to actively link the progress in fighting the AIDS epidemic with efforts to reduce maternal mortality. ${ }^{15}$ This realisation is driving greater collaboration between maternal health and HIV constituencies, and an integrated approach to service delivery, so that women with HIV-and their children-benefit from improved HIV care and treatment and improved reproductive health services. A comprehensive approach to the prevention of motherto-child transmission of HIV could lead to improved services for HIV-infected women, including family planning and early initiation of lifelong antiretroviral treatment for women in need. However, reducing maternal mortality in women with HIV will also require improvements in antenatal care and obstetric services, as well as specific attention to the management of conditions that are aggravated by the underlying HIV infection. The time has come to respond to the call to place maternal health within a continuum of care that integrates a comprehensive range of interventions, to make an impact on maternal, newborn, and childhealth outcomes, including those related to HIV. ${ }^{16}$

\section{Quarraisha Abdool-Karim, Carla AbouZahr, Karl Dehne,} Viviana Mangiaterra, Jack Moodley, Nigel Rollins, Lale Say, Nathan Schaffer, James E Rosen, *Isabelle de Zoysa Centre for the AIDS Programme of Research in South Africa, Durban, KwaZulu Natal, South Africa (QA-K), WHO, 1211 Geneva 27, Switzerland (CAZ, VM, NR, LS, NS, IdeZ); UNAIDS, Geneva, Switzerland (KD); University of KwaZulu Natal, Durban, KwaZulu Natal, South Africa (JM); and Washington DC, USA (JER) dezoysai@who.int

We declare that we have no conflicts of interest. @ World Health Organization, 2010.

1 WHO. Women and health: today's evidence tomorrow's agenda. November 2009. http://www.who.int/gender/women_health_report/en/index.html (accessed March 3, 2010).

2 McIntyre J. Mothers infected with HIV. Br Med Bull 2003; 67: 127-35.

3 Bicego G, Boerma JT, Ronsmans C. The effect of AIDS on maternal mortality in Malawi and Zimbabwe. AIDS 2002; 16: 1078-81.

4 Sewankambo NK, Gray RH, Ahmad S, et al. Mortality associated with HIV infection in rural Rakai district, Uganda. AIDS 2000; 14: 2391-400.

5 Khan M, Thillagavathie P, Moodley J, Connoly CA. Maternal mortality associated with tuberculosis-HIV-1 co-infection in Durban, South Africa. AIDS 2001; 15: 1857-63.

6 Le Coeur S, Khlat M, Halembokaka G, et al. HIV and the magnitude of pregnancy-related mortality in Pointe Noire, Congo. AIDS 2005 19: 69-75.

7 Mbizvo MT, Mmiro FA, Kasule J, et al. Morbidity and mortality patterns in HIV-1 seropositive/ seronegative women in Kampala and Harare during pregnancy and in the subsequent two years. Cent Afr J Med 2005; 51: 91-97.

8 Black V, Brooke $S$, Chersich MF. Effect of human immunodeficiency virus treatment on maternal mortality at a tertiary center in South Africa: a 5-year audit. Obstet Gynecol 2009; 114: 292-99.

9 Louis J, Landon MB, Gersnoviez RJ, et al. Perioperative morbidity and mortality among human immunodeficiency virus infected women undergoing cesarean delivery. Obstet Gynecol 2007; 110: 385-90.

10 Chilongozi D, Wang L, Brown L, et al. Morbidity and mortality among a cohort of human immunodeficiency virus type 1 -infected and uninfected pregnant women and their infants from Malawi, Zambia, and Tanzania. Pediatr Infect Dis J 2008; 27: 808-14.

11 National Committee for the Confidential Enquiries into Maternal Deaths. Saving Mothers 2005-2007: Fourth report on confidential enquiries into maternal deaths in South Africa. 2008. http://www.doh.gov.za/docs/ reports/2007/savingmothers.pdf (accessed March 3, 2010).

12 Samb B, Evans T, Dybul M, et al. An assessment of interactions between global health initiatives and country health systems. Lancet 2009; 373: 2137-69.

13 Price JE, Leslie JA, Welsh M, Binagwaho A. Integrating HIV clinical services into primary health-care in Rwanda: a measure of quantitative effects. AIDS Care 2009; 21: 608-14

14 Hogan MC, Foreman KJ, Naghavi M, et al. Maternal mortality for 181 countries, 1980-2008: a systematic analysis of progress towards Millennium Development Goal 5. Lancet 2010; 375: 1609-23.

15 The Lancet. The Global Fund: replenishment and redefinition in 2010. Lancet 2010; 375: 865.

16 Horton R. What will it take to stop maternal deaths? Lancet 2009; 374: 1400-02. 